\title{
Delivering Benefits at Speed Through Real-World Repurposing of Off-Patent Drugs: The COVID-19 Pandemic as a Case in Point
}

Moshe Rogosnitzky ${ }^{1}$; Esther Berkowitz ${ }^{1}$, MBChB, MA; Alejandro R Jadad ${ }^{2,3}$, MD, DPhil, FRCPC, FCAHS, FRSA, LLD

\footnotetext{
${ }^{1}$ MedInsight Research Institute, Rehovot, Israel

${ }^{2}$ Program in Impactful Giving, Dalla Lana School of Public Health, University of Toronto, Toronto, ON, Canada

${ }^{3}$ Department of Anesthesiology and Pain Medicine, Faculty of Medicine, University of Toronto, Toronto, ON, Canada
}

\author{
Corresponding Author: \\ Moshe Rogosnitzky \\ MedInsight Research Institute \\ Pekeris 4, \\ Weizmann Science Park, \\ Rehovot, 7670204 \\ Israel \\ Phone: 97286220942 \\ Email: moshe@medinsight.org
}

\begin{abstract}
Real-world drug repurposing — the immediate "off-label" prescribing of drugs to address urgent clinical needs-is a widely overlooked opportunity. Off-label prescribing (ie, for a nonapproved indication) is legal in most countries and tends to shift the burden of liability and cost to physicians and patients, respectively. Nevertheless, health crises may mean that real-world repurposing is the only realistic source for solutions. Optimal real-world repurposing requires a track record of safety, affordability, and access for drug candidates. Although thousands of such drugs are already available, there is no central repository of off-label uses to facilitate immediate identification and selection of potentially useful interventions during public health crises. Using the current coronavirus disease (COVID-19) pandemic as an example, we provide a glimpse of the extensive literature that supports the rationale behind six generic drugs, in four classes, all of which are affordable, supported by decades of safety data, and targeted toward the underlying pathophysiology that makes COVID-19 so deadly. This paper briefly summarizes why cimetidine or famotidine, dipyridamole, fenofibrate or bezafibrate, and sildenafil citrate are worth considering for patients with COVID-19. Clinical trials to assess efficacy are already underway for famotidine, dipyridamole, and sildenafil, and further trials of all these agents will be important in due course. These examples also reveal the unlimited opportunity to future-proof our health care systems by proactively mining, synthesizing, cataloging, and evaluating the off-label treatment opportunities of thousands of safe, well-established, and affordable generic drugs.
\end{abstract}

(JMIR Public Health Surveill 2020;6(2):e19199) doi: 10.2196/19199

\section{KEYWORDS}

COVID-19; drug costs; drug repositioning; drugs, generic; off-label use; public health; severe acute respiratory syndrome coronavirus 2; pandemic; crisis

December 2019 heralded the transformation of modern-day life. A new and lethal disease, now named COVID-19, was emerging in China and was about to change the world as we know it. The same month, in propitious timing, a few hundred of the world's leading physicians, scientists, government agency officials, and nonprofit leaders gathered at an inaugural 2-day conference jointly sponsored by the US Food and Drug Administration (FDA) and National Institutes of Health (NIH) in Washington, DC. The topic of the conference was "Repurposing Off-Patent Drugs," and attendees had convened to discuss how widely used, low-cost, and safe medicines that are approved for one indication might be harnessed to provide additional, novel, and sometimes unexpected therapeutic benefits in other diseases.

Dr Christopher Austin, Director of the National Center for Advancing Translational Sciences at the NIH, opened the conference by welcoming the birth of a new era in human medicine. He asked participants "to skewer some sacred cows," emphasizing the need to embrace controversial thinking to improve patients' lives. 
Drug repurposing seems tantalizingly simple. Conservatively, there are 6,500 human diseases that have no regulatory-approved treatments whatsoever. At the current rate of progress, it will be 2,000 years before every human disease is treatable. What percentage of those 6,500 currently untreatable diseases is ameliorable, to some degree, by a drug you can get at [your local pharmacy]? Shame on us if we can't figure out a way to make these available to patients suffering from disabling and lethal diseases. This is an eminently solvable problem.

If drug repurposing was an obscure subject for experts as well as the public, COVID-19 has changed that forever. The publicity generated by the US president endorsing the antimalarial agents hydroxychloroquine and chloroquine as treatments for COVID-19 jolted regulatory authorities worldwide. The FDA felt compelled to grant emergency-use authorization for these drugs, while the European Medicines Agency held back, urging that they should not be prescribed outside of clinical trials and nationally agreed upon protocols. In the absence of proven treatments, many physicians at the frontlines of the COVID-19 battle prescribed these drugs, resulting in a worldwide shortage. Conflicting clinical trial data have emerged since then regarding use of these antimalarial drugs in COVID-19 [1-7], some of which indicate a lack of benefit or even the potential for harm [6]. This underscores the need for emergency regulatory authorization of unproven treatments, if deemed necessary in a public health crisis, to be based first and foremost on robust evidence of safety. It is also important that the relevant agency issues a statement emphasizing the exploratory nature of the intervention and urgent need for robust clinical trial data to support ongoing use.

Hydroxychloroquine and chloroquine were developed as antimalarial treatments and subsequently repurposed for treating systemic lupus erythematosus and rheumatoid arthritis. Their repurposing for these challenging autoimmune diseases was facilitated by funding from pharmaceutical companies, which recouped their investment through patent-protected revenues until the drugs became available as generics. However, only a small proportion of drug-repurposing discoveries enjoy patent protection and can benefit from the large and costly clinical trials necessary for regulatory approval.

By contrast, real-world repurposing — the immediate "off-label" prescribing of drugs by caring physicians based on their acumen, awareness of pilot studies or case reports, or field experience in the clinical setting-is a widely overlooked opportunity. Prescribing a drug off-label (ie, for a use other than what it was approved for) is legal in almost every country worldwide. However, if there is an unforeseen adverse outcome, the burden of liability shifts from the regulator or pharmaceutical company to the prescribing physician. Additionally, the burden of payment shifts from the insurer or other institutional health care payers to the patient. Nevertheless, when dealing with immediate and urgent health crises, whether at an individual or public level, real-world repurposing is frequently the only realistic solution.

To protect the public from unscrupulous players, the US FDA prohibits pharmaceutical companies from promoting off-label uses of their drugs, which could be used to increase profit while avoiding investment in clinical trials. By contrast, the FDA is supportive of disseminating information about promising off-label uses by independent entities, a point reiterated in March 2020 on the FDA's website [8]. This underscores the importance of vigorous efforts to create reliable, independent evidentiary repositories to disseminate such treatment opportunities, and thereby support the decision making of those in the frontlines, in nearly real time.

Two additional critical elements are prerequisites if real-world repurposing is to deliver health benefits at the public level: safety and affordability. The former calls for a decades-long track record of established safety, and the latter requires the availability of generic low-cost drug candidates. Fortunately, many thousands of such drugs are already available. The challenge is that no central repository of off-label uses exists in a way that enables immediate intervention in times of public health crises.

Taking the COVID-19 pandemic as an example, we have selected four well-established drugs backed by many decades of safety data, widespread use, and affordability, which we believe offer the opportunity to prevent or treat both the viral infection and the disabling and deadly complications that ensue. Although COVID-19 usually presents with respiratory symptoms, infection that spreads beyond the lung contributes significantly to the disease toll through uncontrolled outpouring of immune cells, disturbed clotting, multi-organ failure, and other life-threatening complications. There is extensive clinical support, backed by a solid mechanistic scientific rationale, underpinning the proposed drugs (Multimedia Appendix 1). Each was selected based on safety, affordability, and ability to target multiple aspects of the underlying disease processes that make COVID-19 so deadly. The proposed doses are those that have been shown to achieve the target physiological effects as demonstrated in the supporting references.

Cimetidine and famotidine, which are approved for heartburn caused by reflux disease [9], have been shown to have powerful effects on the immune system [10]. Data indicate that they can suppress a wide variety of common viruses, including herpes and human papillomaviruses [11-13], and boost immune response after vaccination [14-20], with additional immune-modulating effects in a range of cancers and allergic diseases [10]. They have also shown efficacy in protecting the heart from excessive workload, lowering blood pressure, and improving cardiac efficiency [21,22]; reducing inflammation [23]; and inhibiting pathological blood clotting [24,25]. A clinical trial of famotidine in COVID-19 was started recently in New York, following the observation (as yet unpublished) that certain patients in China who were taking it when diagnosed with COVID-19 had better clinical outcomes than those who were not [26]. Data generated from this new study are eagerly awaited.

The antiplatelet agent dipyridamole, which is approved to prevent thrombotic events in at-risk patients [27,28], has also caught the eye of researchers investigating potential treatments for COVID-19. A recently published study in China illustrated its ability to suppress the severe acute respiratory syndrome 
coronavirus 2 virus that causes COVID-19, leading to marked clinical improvements [29]. A larger study recently launched in China examines dipyridamole in 460 patients with COVID-19 (ChiCTR2000030055). Beyond these antiviral effects, dipyridamole has shown anti-inflammatory, antioxidant, and vasodilatory activity [30-34], and is one component of a widely used anticoagulant (citrate-theophylline-adenosine-dipyridamole [CTAD]) [35-37]. Clinically, cardioprotective effects have been reported in patients with chronic heart failure [38], and improved renal function is documented in patients with chronic kidney disease, delaying risk of progression to dialysis and reducing mortality $[39,40]$.

The cholesterol-lowering agents fenofibrate and bezafibrate are approved for treatment of dyslipidemias [41]. Although bezafibrate is unavailable in the United States, it is widely used in Europe. Meta-analyses show that they can reduce disability and death from atherosclerotic cardiovascular disease and stroke, independent from their effects on cholesterol $[42,43]$. Potentially protective effects on kidney function have been reported $[44,45]$, along with antiviral efficacy in patients with a hepatitis $C$ virus infection [46]. In some patients, fibrates have lowered plasma fibrinogen levels to a statistically significant degree [47-52], suggesting the potential to address the dangerous hypercoagulability seen in many patients with COVID-19. Indeed, fibrates have demonstrated anticoagulant and cardiovascular protective effects in patients with metabolic syndrome [53], which represents a hypercoagulable state accompanied by inflammation and endothelial dysfunction.

The phosphodiesterase-5 (PDE-5) inhibitor sildenafil citrate is a vasodilator that was approved in 1998 for treating erectile dysfunction [54] and more recently received an indication for pulmonary arterial hypertension (PAH) [55]. Sildenafil has a wide range of anti-inflammatory, antioxidant, and vasodilatory actions across many body systems, with benefits reported in case studies of patients with type 2 diabetes [56,57] and hematological cancers [58]. Reported cardioprotective effects, stemming from improved pulmonary circulation as well as direct action on the myocardium [59], include improved cardiac contractility and reduced symptoms in patients with a range of cardiac disorders [60-62], with reduction in cardiovascular events and mortality in patients at high risk [63]. Studies demonstrating sildenafil's efficacy and tolerability in PAH continue to accrue, and a recent Cochrane review and meta-analysis concluded that patients with PAH who received PDE-5 inhibitors were significantly less likely to die in the short-term than those receiving a placebo [64]. Sildenafil may also reduce mortality in idiopathic pulmonary fibrosis [65], an interstitial lung disease with high mortality, and preliminary evidence suggests that this drug class is actively renoprotective $[62,66]$. Sildenafil is currently under investigation in a phase 3 trial in patients with COVID-19 (NCT04304313), which will help clarify its therapeutic potential.

Times of emergency, such as with the COVID-19 pandemic, call for a radical review of the way we practice medicine. As Dr Austin aptly stated, we have to be ready "to skewer some sacred cows." Clinical trials of unprofitable generic drugs sponsored by governments or nonprofit organizations are obviously welcome and important but should not delay the judicious use of well-established, safe, cost-effective, and rationally prescribed therapies.

The race to find a cure for COVID-19 has resulted in unprecedented worldwide research efforts. As of the time of writing, the Milken Foundation has compiled a list of treatments being studied for COVID-19 [67]. Nevertheless, the time to approval and the expected high cost of the majority of these drugs may leave them out of reach for a large portion of the world's population.

The four well-established drugs presented here for consideration, alone or in combination, for at-risk patients with COVID-19 highlight the gems buried in the mountain of hundreds of thousands of clinical studies, inaccessible to physicians battling at the frontlines of clinical medicine. Unbeknownst to most of them, the four drugs selected in this case, officially approved for a handful of indications, have shown efficacy in managing over 100 additional diseases. We do not propose specifically when or how each of these drugs should be used; rather, we aim to provide a pathophysiological rationale for their use, alone or in combination; share our understanding of why and how they may provide benefit; and spur creative thinking about their potential use in this disease while illustrating the untapped potential of therapeutic options that may be hidden in plain sight.

The COVID-19 pandemic represents an unparalleled opportunity to refocus our efforts on mining, synthesizing, and cataloging the body of evidence behind many promising treatment opportunities. This article is an invitation to kindred spirits and curious, bold humanitarians to pool efforts to harness this opportunity to future-proof our health care systems based on robust science. We owe it to ourselves and future generations.

\section{Acknowledgments}

The views expressed in this publication are those of the authors and not necessarily those of the organizations with which they are affiliated. All authors meet the International Committee of Medical Journal Editors criteria for authorship of this paper and take responsibility for the integrity of the work as a whole. The Uniting History Foundation, Riga, Latvia, provided funding for the development of this manuscript, but had no role in any aspect of manuscript development or review.

\section{Conflicts of Interest}

None declared. 


\section{Multimedia Appendix 1}

Approved indications and recognized physiological effects of drugs to consider repurposing for patients with COVID-19. [DOCX File, 15 KB-Multimedia Appendix 1]

\section{References}

1. Gao J, Tian Z, Yang X. Breakthrough: chloroquine phosphate has shown apparent efficacy in treatment of COVID-19 associated pneumonia in clinical studies. Biosci Trends 2020 Mar 16;14(1):72-73. [doi: 10.5582/bst.2020.01047] [Medline: $\underline{32074550]}$

2. Gautret P, Lagier J, Parola P, Hoang VT, Meddeb L, Mailhe M, et al. Hydroxychloroquine and azithromycin as a treatment of COVID-19: results of an open-label non-randomized clinical trial. Int J Antimicrob Agents 2020 Mar 20:105949 [FREE Full text] [doi: 10.1016/j.ijantimicag.2020.105949] [Medline: 32205204]

3. Gautret P, Lagier J, Parola P, Hoang VT, Meddeb L, Sevestre J, et al. Clinical and microbiological effect of a combination of hydroxychloroquine and azithromycin in 80 COVID-19 patients with at least a six-day follow up: A pilot observational study. Travel Med Infect Dis 2020 Apr 11:101663 [FREE Full text] [doi: 10.1016/j.tmaid.2020.101663] [Medline: 32289548]

4. Chen Z, Hu J, Zhang Z, Jiang S, Han S, Yan D, et al. Efficacy of hydroxychloroquine in patients with COVID-19: results of a randomized clinical trial. medRxiv 2020 Apr 10. [doi: 10.1101/2020.03.22.20040758]

5. Huang M, Tang T, Pang P, Li M, Ma R, Lu J, et al. Treating COVID-19 with chloroquine. J Mol Cell Biol 2020 Apr 01. [doi: 10.1093/jmcb/mjaa014] [Medline: 32236562]

6. Magagnoli J, Narendran S, Pereira F, Cummings T, Hardin JW, Sutton SS, et al. Outcomes of hydroxychloroquine usage in United States veterans hospitalized with Covid-19. medRxiv 2020 Apr 23. [doi: 10.1101/2020.04.16.20065920]

7. Mahevas M, Tran V, Roumier M, Chabrol A, Paule R, Guillaud C, et al. No evidence of clinical efficacy of hydroxychloroquine in patients hospitalized for COVID-19 infection with oxygen requirement: results of a study using routinely collected data to emulate a target trial. medRxiv 2020 Apr 14. [doi: 10.1101/2020.04.10.20060699]

8. US Food and Drug Administration. 2020 Mar 19. Coronavirus (COVID-19) update: FDA continues to facilitate development of treatments URL: https://www.fda.gov/news-events/press-announcements/ coronavirus-covid-19-update-fda-continues-facilitate-development-treatments [accessed 2020-04-07]

9. Merck Manual Professional Version. Gastric acid reducers URL: https://www.merckmanuals.com/professional/ gastrointestinal-disorders/gastritis-and-peptic-ulcer-disease/drug-treatment-of-gastric-acidity\#v892554 [accessed 2020-04-06]

10. Jafarzadeh A, Nemati M, Khorramdelazad H, Hassan ZM. Immunomodulatory properties of cimetidine: its therapeutic potentials for treatment of immune-related diseases. Int Immunopharmacol 2019 May;70:156-166. [doi: 10.1016/j.intimp.2019.02.026] [Medline: 30802678]

11. Kurzrock R, Auber M, Mavligit GM. Cimetidine therapy of herpes simplex virus infections in immunocompromised patients. Clin Exp Dermatol 1987 Sep;12(5):326-331. [doi: 10.1111/j.1365-2230.1987.tb02501.x] [Medline: 3446417]

12. Kapińska-Mrowiecka M, Turowski G. [Efficacy of cimetidine in treatment of Herpes zoster in the first 5 days from the moment of disease manifestation]. Pol Tyg Lek 1996 Jun;51(23-26):338-339. [Medline: 9273526]

13. Harcourt J, Worley G, Leighton S. Cimetidine treatment for recurrent respiratory papillomatosis. Int J Pediatr Otorhinolaryngol 1999 Dec;51(2):109-113. [doi: 10.1016/s0165-5876(99)00279-7]

14. Xie X, Geng S, Liu H, Li C, Yang Y, Wang B. Cimetidine synergizes with Praziquantel to enhance the immune response of HBV DNA vaccine via activating cytotoxic CD8(+) T cell. Hum Vaccin Immunother 2014;10(6):1688-1699 [FREE Full text] [doi: 10.4161/hv.28517] [Medline: 24643207]

15. Zhang W, Wang J, Su B, Li R, Ding Z, Kang Y, et al. Cimetidine augments Th1/Th2 dual polarized immune responses to recombinant HBV antigens. Vaccine 2011 Jun 24;29(29-30):4862-4868. [doi: 10.1016/j.vaccine.2011.03.091] [Medline: 21481324]

16. Wang J, Su B, Ding Z, Du X, Wang B. Cimetidine enhances immune response of HBV DNA vaccination via impairment of the regulatory function of regulatory T cells. Biochem Biophys Res Commun 2008 Aug 01;372(3):491-496. [doi: 10.1016/j.bbrc.2008.04.191] [Medline: 18502198]

17. Bourinbaiar AS, Fruhstorfer EC. The effect of histamine type 2 receptor antagonists on human immunodeficiency virus (HIV) replication: identification of a new class of antiviral agents. Life Sci 1996 Nov;59(23):PL365-PL370. [doi: 10.1016/s0024-3205(96)00553-x]

18. Nielsen HJ, Hammer JH, Moesgaard F, Heron I, Kehlet H. Ranitidine improves postoperative suppression of antibody response to preoperative vaccination. Surgery 1992 Jan;111(1):69-73. [Medline: 1728077]

19. Van der Velden AMT, Van Velzen-Blad H, Claessen AME, Van der Griend R, Oltmans R, Rijkers GT, et al. The effect of ranitidine on antibody responses to polysaccharide vaccines in patients with B-cell chronic lymphocytic leukaemia. Eur J Haematol 2007 Jul;79(1):47-52. [doi: 10.1111/j.1600-0609.2007.00862.x] [Medline: 17532765]

20. Jurlander J, de Nully Brown P, Skov PS, Henrichsen J, Heron I, Obel N, et al. Improved vaccination response during ranitidine treatment, and increased plasma histamine concentrations, in patients with B cell chronic lymphocytic leukemia. Leukemia 1995 Nov;9(11):1902-1909. [Medline: 7475282] 
21. Zhang J, Cai W, Zhang Z, Wang P, Lin X, Feng J, et al. Cardioprotective effect of histamine H2 antagonists in congestive heart failure: a systematic review and meta-analysis. Medicine (Baltimore) 2018 Apr;97(15):e0409. [doi: 10.1097/MD.0000000000010409] [Medline: 29642208]

22. Breuer HM, Hartung H, Goeckenjan G, Abendroth R, Curtius JM, Trampisch HJ, et al. [Cimetidine and ranitidine in intensive care patients. Double-blind randomized cross-over study on intravenous administration: hemodynamics, plasma coagulation, blood gases and acid-base status]. Dtsch Med Wochenschr 1985 Jul 26;110(30):1151-1156. [doi: 10.1055/s-2008-1068976] [Medline: 3893961]

23. Tayama E, Hayashida N, Fukunaga S, Tayama K, Takaseya T, Hiratsuka R, et al. High-dose cimetidine reduces proinflammatory reaction after cardiac surgery with cardiopulmonary bypass. Ann Thorac Surg 2001 Dec;72(6):1945-1949. [doi: 10.1016/s0003-4975(01)03225-8]

24. Nakamura K, Kariyazono H, Shinkawa T, Yamaguchi T, Yamashita T, Ayukawa O, et al. Inhibitory effects of H2-receptor antagonists on platelet function in vitro. Hum Exp Toxicol 1999 Aug;18(8):487-492. [doi: 10.1191/096032799678847069] [Medline: 10462360 ]

25. Mikhailidis DP, Christofides J, Barradas MA, Jeremy JY, Dilawari J, Dandona P. The effect of cimetidine on platelet function: a study involving gastric fluid measurements. Agents Actions 1986 Oct;19(1-2):34-41. [doi: 10.1007/bf01977253]

26. Cohen E. CNN. 2020 Apr 27. New York hospitals are studying a common heartburn drug as treatment for Covid-19 URL: https://www.cnn.com/2020/04/27/health/famotidine-coronavirus-northwell-trial/index.html [accessed 2020-04-27]

27. US Food and Drug Administration. 2019. Persantine (dipyridamole USP) $25 \mathrm{mg}, 50 \mathrm{mg}$, and $75 \mathrm{mg}$ tablets URL: https:/ /www.accessdata.fda.gov/drugsatfda_docs/label/2019/012836s061lbl.pdf [accessed 2020-04-06]

28. Boehringer Ingelheim International GmbH. 2019. Aggrenox: highlights of prescribing information URL: https://docs. boehringer-ingelheim.com/Prescribing\%20Information/PIs/Aggrenox\%20Caps/Aggrenox.pdf

29. Liu X, Li Z, Liu S, Chen Z, Zhao Z, Huang YY, et al. Therapeutic effects of dipyridamole on COVID-19 patients with coagulation dysfunction. medRxiv 2020 Feb 29. [doi: 10.1101/2020.02.27.20027557]

30. Balakumar P, Nyo YH, Renushia R, Raaginey D, Oh AN, Varatharajan R, et al. Classical and pleiotropic actions of dipyridamole: not enough light to illuminate the dark tunnel? Pharmacol Res 2014 Sep;87:144-150. [doi: 10.1016/j.phrs.2014.05.008] [Medline: 24861566]

31. Kim H, Liao JK. Translational therapeutics of dipyridamole. Arterioscler Thromb Vasc Biol 2008 Mar;28(3):s39-s42 [FREE Full text] [doi: 10.1161/ATVBAHA.107.160226] [Medline: 18174451]

32. Guo S, Stins M, Ning M, Lo EH. Amelioration of inflammation and cytotoxicity by dipyridamole in brain endothelial cells. Cerebrovasc Dis 2010 Aug;30(3):290-296. [doi: 10.1159/000319072] [Medline: 20664263]

33. Renvert S, Lindahl C, Roos-Jansåker AM, Lessem J. Short-term effects of an anti-inflammatory treatment on clinical parameters and serum levels of C-reactive protein and proinflammatory cytokines in subjects with periodontitis. J Periodontol 2009 Jun;80(6):892-900. [doi: 10.1902/jop.2009.080552] [Medline: 19485818]

34. Macatangay B, Jackson E, Abebe K, Comer D, Cyktor J, Klamar-Blain C, et al. A randomized, placebo-controlled, pilot clinical trial of dipyridamole to decrease human immunodeficiency virus-associated chronic inflammation. J Infect Dis 2020 Apr 27;221(10):1598-1606. [doi: 10.1093/infdis/jiz344] [Medline: 31282542]

35. Granat F, Monzali C, Jeunesse E, Guerlin M, Trumel C, Geffré A, et al. Comparison of different anticoagulant associations on haemostasis and biochemical analyses in feline blood specimens. J Feline Med Surg 2016 Jul 09;19(4):394-402. [doi: $10.1177 / 1098612 \times 16628579]$

36. Granat FA, Geffré A, Lucarelli LA, Braun JD, Trumel C, Bourgès-Abella NH. Evaluation of CTAD (citrate-theophylline-adenosine-dipyridamole) as a universal anticoagulant in dogs. J Vet Diagn Invest 2017 Sep;29(5):676-682. [doi: 10.1177/1040638717713793] [Medline: 28673194]

37. Yokota M, Tatsumi N, Tsuda I, Nishioka T, Takubo T. CTAD as a universal anticoagulant. J Autom Methods Manag Chem 2003;25(1):17-20 [FREE Full text] [doi: 10.1155/S1463924603000038] [Medline: 18924886]

38. Sanada S, Asanuma H, Koretsune Y, Watanabe K, Nanto S, Awata N, et al. Long-term oral administration of dipyridamole improves both cardiac and physical status in patients with mild to moderate chronic heart failure: a prospective open-randomized study. Hypertens Res 2007 Oct;30(10):913-919. [doi: 10.1291/hypres.30.913] [Medline: 18049022]

39. Kuo K, Hung S, Tseng W, Liu J, Lin M, Hsu C, et al. Dipyridamole decreases dialysis risk and improves survival in patients with pre-dialysis advanced chronic kidney disease. Oncotarget 2018 Jan 12;9(4):5368-5377. [doi: 10.18632/oncotarget.19850] [Medline: 29435184]

40. Lee G, Choong H, Chiang G, Woo K. Three-year randomized controlled trial of dipyridamole and low-dose warfarin in patients with IgA nephropathy and renal impairment. Nephrology 1997;3(1):117-121. [doi:

10.1111/j.1440-1797.1997.tb00201.x]

41. US Food and Drug Administration. 2012. Fenofibrate: highlights of prescribing information URL: https://www. accessdata.fda.gov/drugsatfda_docs/label/2013/021350s013lbl.pdf

42. Hung C, Yang M, Lin M, Lin HY, Lim L, Kuo H, et al. Dipyridamole treatment is associated with improved renal outcome and patient survival in advanced chronic kidney disease. Kaohsiung J Med Sci 2014 Dec;30(12):599-607 [FREE Full text] [doi: 10.1016/j.kjms.2014.10.002] [Medline: 25476097] 
43. Jakob T, Nordmann AJ, Schandelmaier S, Ferreira-González I, Briel M. Fibrates for primary prevention of cardiovascular disease events. Cochrane Database Syst Rev 2016 Nov 16;11. [doi: 10.1002/14651858.cd009753.pub2]

44. Wang D, Tao W, Hao Z, Liu M. Fibrates for secondary prevention of cardiovascular disease and stroke. Cochrane Database Syst Rev 2012 Jan 18;10. [doi: 10.1002/14651858.cd009580]

45. Tomizawa A, Hattori Y, Inoue T, Hattori S, Kasai K. Fenofibrate suppresses microvascular inflammation and apoptosis through adenosine monophosphate-activated protein kinase activation. Metabolism 2011 Apr;60(4):513-522. [doi: 10.1016/j.metabol.2010.04.020] [Medline: 20580385]

46. Grammatikos G, Farnik H, Bon D, Böhlig A, Bader T, Berg T, et al. The impact of antihyperlipidemic drugs on the viral load of patients with chronic hepatitis C infection: a meta-analysis. J Viral Hepat 2014 Aug;21(8):533-541. [doi: 10.1111/jvh.12274] [Medline: 24943517]

47. Jonkers IJAM, de Man FHAF, van Tilburg NH, van der Laarse A, Sandset PM, Smelt AHM, et al. Alterations in the extrinsic pathway in hypertriglyceridemia do not cause a 'procoagulant state': effects of bezafibrate therapy. Blood Coagul Fibrinolysis 2001 Dec;12(8):705-712. [doi: 10.1097/00001721-200112000-00013] [Medline: 11734672]

48. Ceska R, Sobra J, Kvasnicka J, Procházková R, Kvasilová M, Haas T. [The effect of micronized fenofibrate on lipid parameters and fibrinogen in heterozygous familial hypercholesterolemia and familial combined hyperlipidemia]. Cas Lek Cesk 1996 Jul 26;135(13):413-416. [Medline: 8925538]

49. Durrington P, Mackness M, Bhatnagar D, Julier K, Prais H, Arrol S, et al. Effects of two different fibric acid derivatives on lipoproteins, cholesteryl ester transfer, fibrinogen, plasminogen activator inhibitor and paraoxonase activity in type IIb hyperlipoproteinaemia. Atherosclerosis 1998 May;138(1):217-225. [doi: 10.1016/s0021-9150(98)00003-3]

50. Sahebkar A, Serban M, Mikhailidis DP, Toth PP, Muntner P, Ursoniu S, LipidBlood Pressure Meta-analysis Collaboration (LBPMC) Group. Head-to-head comparison of statins versus fibrates in reducing plasma fibrinogen concentrations: a systematic review and meta-analysis. Pharmacol Res 2016 Jan;103:236-252. [doi: 10.1016/j.phrs.2015.12.001] [Medline: $\underline{26657419]}$

51. Maison P, Mennen L, Sapinho D, Balkau B, Sigalas J, Chesnier M, et al. A pharmacoepidemiological assessment of the effect of statins and fibrates on fibrinogen concentration. Atherosclerosis 2002 Jan;160(1):155-160. [doi: 10.1016/s0021-9150(01)00552-4]

52. Madrid-Miller A, Moreno-Ruiz LA, Borrayo-Sánchez G, Almeida-Gutiérrez E, Martínez-Gómez DF, Jáuregui-Aguilar R. Ipact of bezafibrate treatment in patients with hyperfibrinogenemia and ST-elevation acute myocardial infarction: a randomized clinical trial. Cir Cir 2010;78(3):229-237. [Medline: 20642906]

53. Kilicarslan A, Yavuz B, Guven GS, Atalar E, Sahiner L, Beyazit Y, et al. Fenofibrate improves endothelial function and decreases thrombin-activatable fibrinolysis inhibitor concentration in metabolic syndrome. Blood Coagulation Fibrinolysis 2008;19(4):310-314. [doi: 10.1097/mbc.0b013e3283009c69]

54. Pfizer Laboratories Div Pfizer Inc. 2017 Nov. VIAGRA- sildenafil citrate tablet, film coated: highlights of prescribing information URL: http://labeling.pfizer.com/showlabeling.aspx?id=652 [accessed 2020-03-31]

55. US Food and Drug Administration. 2014 Jan. Revatio (sildenafil): highlights of prescribing information URL: https://www. accessdata.fda.gov/drugsatfda docs/label/2014/021845s011,022473s004,0203109s002lbl.pdf

56. Santi D, Giannetta E, Isidori AM, Vitale C, Aversa A, Simoni M. Therapy of endocrine disease: effects of chronic use of phosphodiesterase inhibitors on endothelial markers in type 2 diabetes mellitus: a meta-analysis. Eur J Endocrinol 2015 Mar;172(3):a. [doi: 10.1530/eje-14-0700]

57. Aversa A, Vitale C, Volterrani M, Fabbri A, Spera G, Fini M, et al. Chronic administration of Sildenafil improves markers of endothelial function in men with type 2 diabetes. Diabet Med 2008 Jan;25(1):37-44. [doi: 10.1111/j.1464-5491.2007.02298.x] [Medline: $\underline{18199130]}$

58. Kniotek M, Boguska A. Sildenafil can affect innate and adaptive immune system in both experimental animals and patients. J Immunol Res 2017;2017:4541958. [doi: 10.1155/2017/4541958] [Medline: 28316997]

59. Hutchings DC, Anderson SG, Caldwell JL, Trafford AW. Phosphodiesterase-5 inhibitors and the heart: compound cardioprotection? Heart 2018 Aug;104(15):1244-1250. [doi: 10.1136/heartjnl-2017-312865] [Medline: 29519873]

60. Tzoumas N, Farrah TE, Dhaun N, Webb DJ. Established and emerging therapeutic uses of PDE type 5 inhibitors in cardiovascular disease. Br J Pharmacol 2019 Nov 12. [doi: 10.1111/bph.14920] [Medline: 31721165]

61. Mostafa T. Non-sexual implications of phosphodiesterase type 5 inhibitors. Sex Med Rev 2017 Apr;5(2):170-199. [doi: 10.1016/j.sxmr.2016.02.004]

62. Brown KE, Dhaun N, Goddard J, Webb DJ. Potential therapeutic role of phosphodiesterase type 5 inhibition in hypertension and chronic kidney disease. Hypertension 2014 Jan;63(1):5-11. [doi: 10.1161/HYPERTENSIONAHA.113.01774] [Medline: 24101666]

63. Anderson SG, Hutchings DC, Woodward M, Rahimi K, Rutter MK, Kirby M, et al. Phosphodiesterase type-5 inhibitor use in type 2 diabetes is associated with a reduction in all-cause mortality. Heart 2016 Nov 01;102(21):1750-1756. [doi: 10.1136/heartjnl-2015-309223] [Medline: 27465053]

64. Barnes H, Brown Z, Burns A, Williams T. Phosphodiesterase 5 inhibitors for pulmonary hypertension. Cochrane Database Syst Rev 2019 Jan 31;1. [doi: 10.1002/14651858.cd012621.pub2] 
65. Rochwerg B, Neupane B, Zhang Y, Garcia CC, Raghu G, Richeldi L, et al. Treatment of idiopathic pulmonary fibrosis: a network meta-analysis. BMC Med 2016 Feb 03;14:18. [doi: 10.1186/s12916-016-0558-x] [Medline: 26843176]

66. Webb DJ, Vachiery J, Hwang L, Maurey JO. Sildenafil improves renal function in patients with pulmonary arterial hypertension. Br J Clin Pharmacol 2015 Aug;80(2):235-241. [doi: 10.1111/bcp.12616] [Medline: 25727860]

67. Milken Institute. COVID-19 treatment and vaccine tracker URL: https://milkeninstitute.org/sites/default/files/2020-03/ Covid19\%20Tracker\%20NEW3-30-20.pdf?mod=article inline [accessed 2020-04-06]

\title{
Abbreviations \\ COVID-19: coronavirus disease \\ FDA: Food and Drug Administration \\ NIH: National Institutes of Health \\ PAH: pulmonary arterial hypertension \\ PDE-5: phosphodiesterase-5
}

\author{
Edited by G Eysenbach; submitted 07.04.20; peer-reviewed by D Cavalla, H Demonaco; comments to author 25.04.20; revised version \\ received 29.04.20; accepted 05.05.20; published 13.05.20 \\ Please cite as: \\ Rogosnitzky M, Berkowitz, E, Jadad AR \\ Delivering Benefits at Speed Through Real-World Repurposing of Off-Patent Drugs: The COVID-19 Pandemic as a Case in Point \\ JMIR Public Health Surveill 2020;6(2):e19199 \\ URL: http://publichealth.jmir.org/2020/2/e19199/ \\ doi: $\underline{10.2196 / 19199}$ \\ PMID: $\underline{32374264}$
}

CMoshe Rogosnitzky, Esther Berkowitz, Alejandro R Jadad. Originally published in JMIR Public Health and Surveillance (http://publichealth.jmir.org), 13.05.2020. This is an open-access article distributed under the terms of the Creative Commons Attribution License (https://creativecommons.org/licenses/by/4.0/), which permits unrestricted use, distribution, and reproduction in any medium, provided the original work, first published in JMIR Public Health and Surveillance, is properly cited. The complete bibliographic information, a link to the original publication on http://publichealth.jmir.org, as well as this copyright and license information must be included. 